\title{
LAW ENFORCEMENT IN ISLAM
}

\author{
Djawahir Hejazziey \\ UIN Syarif Hidayatullah Jakarta \\ Jl. Ir. H. Juanda No. 95, Ciputat, Jakarta Selatan \\ E-mail: djawahirhejazziey@gmail.com
}

\begin{abstract}
Abstrak. Penegakan Hukum dalam Islam. Artikel ini memberikan penjelasan bahwa teori Lawrence Friedman yang dikenal dengan three elements of legal system dalam penegakan hukum terdapat kekurangan yang signifikan, jika dibandingkan dengan teori yang terdapat di dalam Alquran, dimana di dalamnya dijelaskan bahwa penegakan hukum harus ada unsur kesadaran dari masyarakat itu sendiri, seperti diabadikan dalam kisah Nabi Ibrahim dan Ismail. Untuk menegakan keadilan tidak hanya meliputi tiga unsur atau pilar saja, tapi juga yang tidak kalah pentingnya harus memasukan unsur masyarakat hukum atau adanya kesadaran hukum dari masyarakat itu sendiri. Penegakan hukum tidak akan bisa terlaksana dengan baik, apabila si tersangka tidak memiliki kesadaran akan pentingnya keadilan sebagai tujuan dan mahkota hukum.
\end{abstract}

Kata kunci: penegakan hukum, Islam, hukum

\begin{abstract}
Law Enforcement in Islam. This article explains that the theory of Lawrence Friedman, known as the Three Elements of the legal system in law enforcement there is a significant short age, when compared with the theory contained in the Qurân, where it is explained that law enforcement should be no element of awareness of society itself, as enshrined in the story of Prophet Ibrahim and Ismail. To uphold justice not only includes three elements or pillars, but also the equally important need to incorporate elements of the law society or the legal awareness of the society itself. Law enforcement will not be performing well, if the suspect does not have the awareness of the importance of justice as law and crown law purposes.
\end{abstract}

Keywords: law enforcement, Islam, legal

\section{Introduction}

Many issues of global criminal loose and escape from the law enforcement whether due to inconsistencies in application of the law or because the law to be applied and the blunt or the people do not care about the law, to the person who suspects, always shy away from the demands of law.

There are three major pillars of the legal system, according to Lawrence M Friedman's concept ${ }^{1}$, which can give effect to the enforcement and application of the law: (1) The law regarding the institutional structure and the various institutions that have the authority to make and implement laws. (2) A legal substance containing material, rules, norms, rules and real patterns and behavior of the people who are in the form of legislation. (3) A cultural or legal culture attitudes towards law, espoused beliefs, values, thoughts and hopes. These pillars have become experts consensus of existing law. So with only by three pillars this law can be upright.

Islam complements of these pillars. Islam considers the three pillars that were not enough, the suspect must

Recived: 10th September 2014, revised: 8th November 2014, accepted: $1^{\text {st }}$ December 2014.

${ }^{1}$ Lawrence Friedman, American Law, (London: W.W. Norton \& Company, 1984), p. 6. be an awareness on the part of the component, so that it becomes four pillars or components. The fourth pillar, is accused awareness or defendant really should have awareness of the rule of law. It is narrated in the Q.s. alShshâffât [37]:102, when Ibrahim was ordered by God to slaughter his son (Ismail). Ismail stated compliance, obedience, awareness and readiness to be sacrificed or slaughtered as a law or God's commands.

When four of these are met, then the law will automatically be upright. If the law isu held then justice will be created, because the justice system itself as the crown and legal purposes.

\section{Steps of the Law Enforcement}

Enforcement is a process, method, act ${ }^{2}$. The law is the overall regulations or rules in a life together, the overall rules of conduct that apply in life together, which can be enforced by a sanction implementation. And the law also serves as protection of human interests, so that human interests are protected, then the law should be implemented. And in law enforcement, there are two elements, the rule of law

${ }^{2}$ Departemen Pendidikan dan Kebudayaan, Kamus Besar Bahasa Indonesia, (Jakarta: Balai Pustaka, 2005), Edisi III, p.1155. 
(rechtssicherheit) and justice (gerechtigkeit). ${ }^{3}$

Laws are rules that define people's rights and responsibilities toward society ${ }^{4}$. Laws are agreed on by society and made official by governments. Some persons look on laws with fear, hatred or annoyance. Laws seem to limit people's freedom to do many things they would like to do. Though laws may prevent us from doing things we wish to do at the moments, laws also stop others from acting on wishes that might harm us. Laws make everyone's life safer and more pleasant. Without laws we could not hold on to our property. We could not go to bed at night expecting to wake up in the morning and find that we had not been robbed. No stores in which we buy food, clothes and other necessities could stay open and sell to us. Our banks would not be safe for our money.

Social life would be impossible without laws to control the way people treat one another. It is not the laws that should be feared but the trouble that come to everyone when laws are broken. Once this is understood, a citizen will not feel fear or hatred of law. Understanding the need for good laws and the evil results of breaking laws is the first requirement of good citizenship and government.

Philosophers once believed that in pre-historic times people live without laws in a state of nature. People were free to do as they pleased unless someone stronger stopped them from by force. As a result, life became so dangerous and unsafe that leaders had to create laws to protect life and property.

To promote the general welfare in order to achieve the ideals of the opening of the 1945 Constitution, the need for treatment of people who uphold the law and justice. As a consequence of this, the law must be obeyed, the law must be upheld and the rule of law, either by state officials as well as by members of the community.

There are four steps in law enforcement, in addition to the factors above mentioned components. In the realization of law enforcement to do is: (1) Arrest of the suspect ${ }^{5}$, detain a person suspected of an enforcement measures or application of the law. Step detain any person who commits an offense or crime could be due to the above reports and public complaints or being caught when the actors do a crime or offense immediately known by the authorities. The role of law enforcement officers must function and perform tasks as well as possible. (2) Decision about the suspect's guilt or innocence,the process of determining whether the defendant actually made a mistake or not, should examine the causes of the criminal conduct and review matters relating to the substance of the law itself.

\footnotetext{
3 Sudikno Mertokusumo, Mengenal Hukum Suatu Pengantar, (Yogyakarta: Tiga Serangkai, 1999), p. 145.

${ }^{4}$ Macmillon, The New Book of Knowledge, (America: Grollier, First Edition, 1970), p. 635.

${ }^{5}$ Macmillon, The New Book of Knowledge, p. 637.
}

(3) Sentencing, if the suspect is found guilty, punishment is not an easy thing, the judge must decide based on the study of mind and naql. Giving the decision is not based on the "like and dislike", not because a group of organizations, or for things that are prohibited by ethics propfesi, but really simply because the task of justice, because God alone. (4) And execution of the sentence or punishment, in this last step, it takes execution function and role is not only a deterrent effect on the defendant, but also to the family and community components of the state.

\section{Urgency of Law Enforcement Institutions}

Seen from today's law enforcement, not a few people associated with the case law and participate trapped in a fatal error and resulted in the collapse of a country's legal pole. If this happens often result would be a misuse of the law.

Measures and strategies is urgent to be done at this time, as a solution to the problem is to reform and restructuring of the existing law. As the people of Indonesia, the country was in desperate need of law enforcement fair and firm. There is no discrimination in the enforcement, but as it is to know that one of the reasons behind the lack of law enforcement in Indonesia is still low morality of law enforcement officials (judges, police, prosecutors and lawyers) and judicial corruption that is already ingrained so far difficult completely eradicated.

The existence of a clear judicial corruption in Indonesia complicate law enforcement because law enforcement officers are supposed to enforce the law even sometimes participate engage in corrupt practices, making it difficult disciplined and community expectations that the government can create good govement. Law enforcement can only be done if the legal institutions to act professionally, has a noble character, honest and apply the principles of good govement.

BusyroMuqoddas, noting four major factors that caused the Indonesian justice system become corrupt as it is today: (1) Very low morality of law enforcement officers, such as police officers, prosecutors, clerks, judges, and lawyers in practice working with the barons, and political actors. (2) The corrupt political culture has flourished in the state bureaucracy and feudalistic government, not transparent and there is no power of community control. (3) High apathy and ignorance of the public about the meaning and work forces that play a role in the criminal practice. (4) Criteria and recruitment process of police officers, prosecutors and judges are still not fully transparent and professional. (5) Low willingness of state (political will) in combating judicial mafia practices seriously and honestly.

Failure due to the inability of law enforcement looks at the enforcement process is not transparentand honest, even 
the legal case the opportunity to be the object of extortion. More ironically, the judicial mafia practices already exist of stages of the investigation to the judicial process.

Of course the most important is the issue of integrity and morality of law enforcement is becoming more and more alarming. The issue reminds us of the moral decadence that occurred on 6th century $\mathrm{AD}$. At the time of human civilization is almost destroyed, also due to the moral issues that have been lost, then the coming of the Prophet Muhammad by Allah is to foster human morality has been almost extinct.

The historical facts show the importance of the role of humans in the moral harmony of human life in the world. Therefore, it is believed that the appearance of legal mafia movement actually originated from the question of the decline of integrity and morality of law enforcement, in addition to other factors such as the classic excuse of inadequate law enforcement salaries, strong currents of temptation distorted justice seekers and others.

\section{Responsibilities of Law Enforcement}

The law has a strategic and dominant position in the public life of nation and state. Law as a system, can act properly in society, if the instrument is equipped with implementation powers in the field of law enforcement. Implementation of the law can take place normally, but it can also occur because of a violation of law, therefore, has violated the law should be enforced. According to Gustav Radbruch, there are three main elements / goals in law enforcement, justice, rule of law and legal expediency.

Indonesia is a State based on law (rechstaat), not the state that is based on power (machstat), as seen in the Constitution of 1945 in Article 2, paragraph 1 that Indonesia is a country based on law (rechstaat).

One of the important pillars of the country was a judicial law impartially and without the intervention of any party, due process of law must run properly handled proportionately from the rules of the legal and law enforcement professionals. ${ }^{6}$

We recognize the existence of perverted justice, namely the failure judicial process and all its aspects. This occurs because the court failed to process offenders appropriately and correctly and failed to apply the law as it should be. ${ }^{7}$

Law enforcement is the duty and responsibility of the community and justice institutions include: police, prosecutors, courts and advocacy organizations that exist

${ }^{6}$ Amir Syamsudin, "Integritas Penegak Hukum, Hakim, Jaksa, Polisi dan Pengacara", dalam Harian Umum Kompas, edisi Juni 2008.

7 "Laporan Mafia Peradilan Meningkat", artikel diakses pada tanggal 19 Mei 2010 http://jambiindependent.co.id/jio/index.php?option=com_ content\&view=article\&id=5506:laporan-kasus-mafia-peradilan-meningk at\&catid $=25$ :nasional\&Itemid $=29$ (lawyer). The realization of a just law enforcement and ensure legal certainty is the hope of all citizens who have a sense of justice and has long been expecting agencies mentioned above play an active role in upholding the public sense of justice.

Law enforcement as part of a legal system that can not be separated from the substance of the law (legal subtance) and the culture of law (legal culture). Law as a socio-empirical symptoms assessed in the independent variable gives impact on many lives. Aspects of social life is becoming dependent variable, then it can be studied law in action and the legal impact.

Reviewing the law as independent variables, including the study of law and society. Conversely, if the law is used as the dependent variable, then the law including studies sociology (sociology of law). Difference between the two is that the study of law and society is specialization in law, while the law is a specialization sociology. The similarity is that both are no longer looking at the law as a rule solely and have-dogmatif relativize the normative nature of law.

\section{Lack of Awareness Against Legal Understanding}

Lack of awareness of common law causes of inequality, between the legal discretion by law. Legal awareness is not only directed to people who are said to be less aware of the law, but also law enforcement officers. ${ }^{8}$ Laws serve as a social control premises accompanied by the threat of sanctions can not be applied by itself without any human action is referred to as law enforcement officers and communities.

Law enforcementis often called by the application of the law is a stage where the rules of law or policy are conducted in a concrete way in the daily life of the community.'People's behavior also determines whether the law will be the law of behavior or not, so that legal awareness be the determining factor. Consciousness is a control law so that the law was made and carried out in their best. According to a large dictionary of Indonesian, legal awareness is the knowledge that a certain behavior is governed by the law so that there is a tendency to follow the rules. ${ }^{10}$

Legal awareness is the values that live preformance on the legal community, including the knowledge, understanding, appreciation, compliance and obedience to law. ${ }^{11}$ Growing awareness of the effectiveness of the law is required. The law will be effective when the component factors of enforcement can work well, such as the commitment of

\footnotetext{
${ }^{8}$ Nur Rohim Yunus, Restorasi Budaya Hukum Masyarakat Indonesia, (Jakarta: Jurisprudensi Press, 2012), p. 93.

9 Satjipto Raharjo, Ilmu Hukum, (Bandung: PT Citra Aditya Bakti,1996), p. 181.

${ }^{10}$ Departemen Pendidikan dan Kebudayaan, Kamus Besar Bahasa Indonesia, p.876.

${ }^{11}$ Soejono Soekanto, Faktor-Faktor yang Mempengaruhi Penegakan Hukum, (Jakarta: Rajawali, 1983), p. 55.
} 
law enforcement, both the formation of law and the rule of law and the existence of community support.

Law enforcement officials will be considered deviant, when in the process of law-making rule out the values in a society that only benefits a certain group, a certain class, power,rich people and so on, and the enforce ability, venal officials. The community also developed a culture that is not conducive and support the establishment of vigilante law, are not friendly with the authorities. Finally, the nature of the regularity of the system as a myth. And the reality of that happening is a conflict in the legal system, because each component and sub-system thins took part in law enforcement.

The public is now questioning the performance of law enforcement agencies in combating corruption as an outbreak of justice or in other words, the"trade law". The failure of the judiciary in achieving the purpose of the law has prompted increasing distrust of the institutions of law and legal institutions. Yet, this is precisely the value of trust that must be upheld and protected by law. Enforcement authority of the law in essence, means that the value of trust in the enforcement of the law of society which will affect the public to submit to the law.

According Soejono Soekarno, the lawwill be effective, if: (1) The presence of role models legal compliance by law enforcement, (2) The firm stand of the apparatus, (3) Information and counseling about regulations will apply to the public, (4) Provide adequate time for the public tounder stand legal, (5) Adjustment rules applicable to the development of cutting-edge technology.

Law enforcement and the community have the same function in law enforcement, law enforcementis good when unregulated in adequate, then the law enforcement can not walk properly. The community should have a high awareness of the law, do not feel pressured or feel any compulsion. In other words, if all components of the legal upright as officers of law, law and society are able to work together. But if one is not working properly, then the law is only discourse.

\section{Law Enforcement in Islamic Perspective}

Conceptually, the core of the rule of law lies in aligning activity relationship values. Law enforcement should be done firmly indiscriminately against violators of the law. Law enforcement should not be done as the knife used to cut down just sharp, but blunt upwards. In fact, the Qurân clearly and vividly outlines Q.s. al-Nisâ [4]: 58:

Verily! Allah commands that you should render back the trusts to those, to whom they are due and that when you judge between men, you judge with justice. Verily, how excellent is the teaching which He (Allah) gives you! Truly, Allah is Ever All Hearer and All Seer.

Law enforcement institutions are institutions of justice in a society, where public institutions require and seek justice. Ideally, law enforcement agencies should not be the slightest waver in implementing justice based on the law and the law that has been agreed upon. In accordance with what God has recommend that every human being to be fair to one another, in order to realize the satisfaction of all those who seek justice and to obtain legal certainty. This also has been included in the Q.s. al-Nahl [16]: 90:

Verily, Allah enjoins al-'adl (justice and worshipping none but Allah Alone - Islamic Monotheism) and al-ihbsân (to be patient in performing your duties to Allah, totally for Allahs sake and in accordance with the Sunnah (legal ways) of the Prophet Saw. in a perfect manner) and giving (help) to kith and kin (all that Allah has ordered you to give them, wealth, visiting, looking after them or any

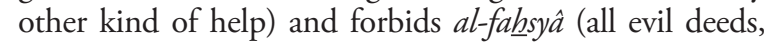
illegal sexual acts, disobedience of parents, polytheism, to tell lies, to give false witness, to kill a life without right, etc.), and al-munkar (all that is prohibited by Islamic law: polytheism of every kind, disbelief and every kind of evil deeds, etc.), and al-baghy (all kinds of oppression), $\mathrm{He}$ admonishes you, that you may take heed.

Justice to put a man equal before the law. Here the principle of equal before the law, to be realized, but implemented. The Prophet said that if Fatimah binti Muhammad steal, he will cut off her hand.

\section{Closing Remarks}

In Islam, To uphold justice not only includes three elements or pillars, but also the equally important need to incorporate elements of the law society or the legal awareness of the society itself. Law enforcement will not be performing well, if the suspect does not have the awareness of the importance of justice as law and crown law purposes.[]

\section{Bibliography}

Apedorn, Van L.J, Pengantar Ilmu Hukum, Jakarta: Pradnya Pramita, 1986.

Asshiddiqie, Jimly, Konstitusi dan Konstitosionalisme Indonesia, Jakarta: Sinar Grafika, 2010.

Atmasasmita, Romli, Reformasi Hukum, Hak Asasi Manusia dan Penegakan Hukum, Jakarta: Sinar Baru Ofset,2001.

Azhari, Muhammad Tahir, Negara Hukum, Jakarta: Kencana Prenada Media Group, Cet. 4, 2010.

Black, Donald, Behariour of Law, New York, San Fransisco, London: Academic Press, 1976.

Dirdjosisworo, Sudjono, Sosiologi Hukum Studi tentang Perubahan Hukum \&Sosial, Jakarta: CV. Radjawali Press, 2012.

Dossy, Iskandar dan Tanya, L. Bernard, Hukum Etika Kekuasaan, Yogyakarta: Genta Publishing, 2011. 
Friedman, Lawrence, American Law, London: W. W. Norton \& Company, 1984.

Hommes, Van Eikema, Logika en Rachtvinding, Tanpa KotaVrieje Universiteit, Tanpa Tahun.

Macmillon, The New Book of Knowledge, America: Grollier, First Edition, 1970.

Majelis Permusyawaratan Rakyat Reoublik Indonesia, Panduan Pemasyarakatan Undang-Undang Dasar Negara Republik Indonesia Tahun 1945, Jakarta: Sekretariat Jenderal MPRRI, 2008.

Manan, Abdul, Aspek-Aspek Pengubah Hukum, Jakarta: Kencana Prenada Media, 2009.

MertoKusumo, Sudikno, Bab-Bab tentang Penemuan Hukum, Yogyakarta: Citra Aditya Bhakti, 1993.
Rahardjo, Sacipto, Ilmu Hukum, Bandung: Alumni, 1989.

Skolnick, Jerome, H. Justice Without Trial, Law Enforcement in Democratice Society, New York, Second Edition, 1975.

Soekanto, Soejono, Faktor-Faktor yang Mempengarubi Penegakan Hukum, Jakarta: PT. Rajagrafindo Persada, 2011.

Soekanto, Soejono, Pokok-Pokok Sosiologi Hukum, Jakarta: PT. Rajagrafindo Persada, 2012.

Usman, Sabian, Dasar-Dasar Sosiologi Hukum; Makna Dialog Antara Hukum dan Masyarakat, Yogykarta, Pustaka Pelaja, 2009.

Yunus, Nur Rohim, Restorasi Budaya Hukum Masyarakat Indonesia, Bogor: Jurisprudence Press, 2012. 
